がなかつたら，次に栓の磨り合せ部分 (第 1 圖のb の部分) を(1)に述べたと同じ方沠でショックを與へて見る. そし て(1)の方泆を交互に行つて見る.

（3）上述の (1)，(2) の方法で動かなければ第了圖に示す

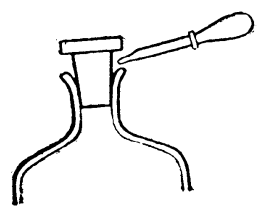

第 3 圖 よらに栓と踢の口の接する溝に スポイトを用ひて10〜20\%位の 稍濃厚な节性アルカリ溶液を滴 下した後磨り合せ部分の外周を ブンゼンバーナーか确子管の 先に點じた弱い小焰で溫めてや る.この時强い火を用ひたり急 激に溫めたりすると鵝裂を生しることがあるから徐々に急 がず行ふ必要がある. 以上の操作を行ふ際, 鐠䁗を弱い加 熱板上で泪めておいてからアルカリを滴下寸れは鐠內部が 減壓になつてるるからアルカリの磨り合せ面內への浸透も 早く行はれる.

アルカリカ成る可く廣く磨り合せ面內に浸透して磨り合 せ面の白色不透明の部分が少くなつたら(1)及で(2)に述べ た操作を行ふ.（1) (2) の操作を行ひ乍らその合間々々に アルカリ滴下加溫を行つて見る．暫くこれを續けてをれば 必ず栓は動くようになる。

（4）以上の操作を行ふとき決して焦つて無理な栓の動か し方や强いショック，强い加熱を與へるようなことをして はならない.焦ると必ず失敗し破損する.著者は上述の操作 を最長 50 分行つて固着したメスフラスコの栓をとつた事 がある. 一度に栓を動かさうとしても動かない場合は時を 改めて陉作を繼續し氣永にやる事が大切である. 郝性アル カリはガス分析その他の廢液例へば Hempel の吸收液, 鐵鋼中窒素分析法の吸收液等を用ひればよい。

本法は第 1 圖の例以外にも應用可能である.

III. 固着せるゴム栓の分敨法

(1) Bailey 法：道具としてガラス管切断の時管に傷を つけるのに用ひる小型の三位鑢を用意する.

寒暖計を一方の手に持ち鑢の先の細くなつた六住形つ柄 の先をゴム栓の下側の゙ガラスから終 $1 / 8$ 时㒕れた所にさし 込を. 第4圖に示すように右手の先を自分の體の方に向けて 廻はす.鎴の柄は摩擦係數の著しく相違するゴムとガラス の間にはさみ込まれてるるので右手を迴はすと鑢のガラス に接する側はすべるがゴムに接する側はゴムに引找かり中
に食ひ込む．この回轉を續行するとゴムはガラスの正面か ら垂间に引き上げられてゴムはガラスから引き離される. 塞暖計の㕆圍つ一部が㒕された後は鏬の軸を（第 4 圖に示 す樣に) 手を體の方に動かすことにより移動させる，そう

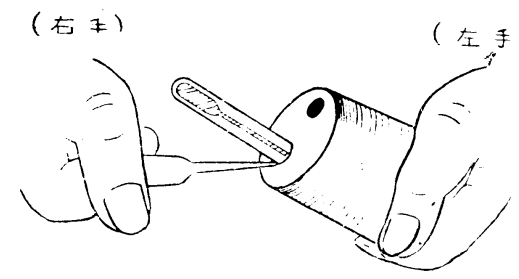

第 4 圖

すると鑢の柄が寒暖計の園に沿つて動くから錿の柄は盆々 媣くゴム栓の中に入つて遂に先端が汳對侧に出るよろにな る.

（2）Paskin 法: Bailey 法と同栏なるも鑢を差し込む時 にガラスとゴム栓との間に 1〜2滴の水をさ寸とその後の ゴム栓の舦離が非常に容易となる.

(3) Robinson 法: Robinson は上述の二者の方法上り 更に簡單安全な方法として次の方法を報じてるる. 即ち拢 きとらんとする寒暖計又は管の外俓より僅かに大きいコル クボーラーをとりその先をグリセリンか又は $\mathrm{NaOH}$ 溶液 で濕めす。これを寒暖計又は管の端にはめて

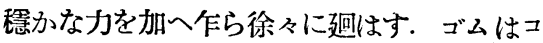
ルクボーラーによつて切られることなくガラ スから引き跳される．そらして次第にゴム栓 をコルクボーラーは拔けて塞暖計を分腓して くれる. 時々コルクボーラーに上記の減摩卿 をやるとよい，以上の模樣を 圖示したのが 第 5 圖である.

IV. 結 言

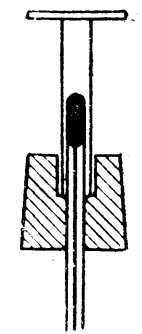

著者の經驗に基いて固着せるガラス磨り合せ爆栓類の安 全確實な分離方法を述へた。

(1) "Removal of Adhered Ruffer Stoppers". Ind. Eng. Chem., Anal. Ed., 12 (1.940). 52.

(2) Ind. Eng. Chem., Anal. Ed., 12 (1940), 224.

(3) ditto.

[昭和 22 年 7 月 3 日受理]

\title{
水銀陰極による鐵の電解分離法
}

\section{日鐵入幡製鐵所技術研究所池上卓 穗}

\section{I. 緒 言}

鐵銀分析に於て鐵の分離法として水銀を除極として電解 し溶液中の鐵イオンを水銀中に吸收せしめて除去する方法
があり 鐵鋼中の $\mathrm{Al}(1)$ 或は $\mathrm{V}^{(2)}$ の分析に月用ひられてをり その場合の電解條件が示されてるる ${ }^{(3)}$ が笔解中溶液中の鐵 イオンガ如何なる狀態にあるか又緎イオンの分㒕か如何に 
行はれるかについては今迄に告報さたれものが見當らな い. 著者はこれ等の點を明らかにすることは水銀陰極によ る鐵イオンの電解分離を行ふ上に必要であると考へ次の實 㹂を試みた。

\section{II. 實 驗 方 法}

水銀院極を用ひる電解法の諸條件は G. E. F. Lundell, J. I. Hoffman 及び H. A. Bright 著 Chemical Analysis of Iron and Steel 47頁と U. S. Steel Corp. の Sampling and. Analysis of Carbon and Alloy Steels, (1938) 165頁, 205頁とに詳しく述べてあるが著者は前者を參照し つつ大體後者 (205頁)の方法に從つて實驗する事とした.

郎ち電解溶器は第 1 圖に示す如き寸法の Melaven Cell を 用ひ陰極水銀量は $900 \mathrm{~g}$ を使用し陰極面积を $39.5 \mathrm{~cm}^{2}$ にな る樣にした。

陽極は第 1 圖に示す如き白金圓板を用ひ陰極水银面から

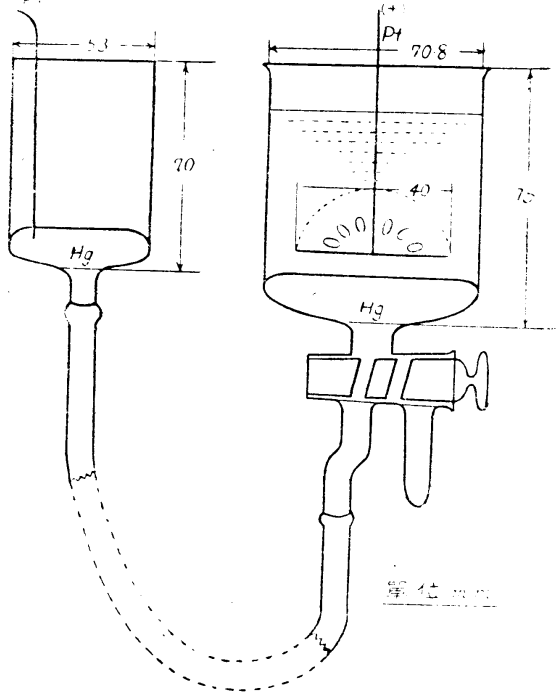

第 1 圖

$1 / 4$ 时以內に來る樣にし電解中回轉さして液を摼拌した
電流密度は $0.16 \mathrm{Amp}$ per $\mathrm{cm}^{2}$ とした。水銀は稀㗂酸々性 とした $5 \% \mathrm{HgNO}_{3}$ 水溶液中を雨下せしめたる後稹空蒸溜

して精製したものを肺ひた。試料溶液は次の如くして作製.

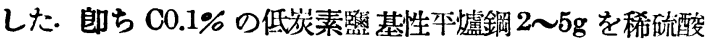
(1:9) 30〜60cc に加熱溶解 後不溶解殘渣を滤別した後濾

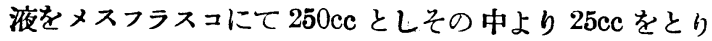
アンモニア水で中和し $\mathrm{H}_{2} \mathrm{SO}_{4}(1: 9) 2 \mathrm{cc}$ を加へ更に水を 加へて 75cc として冷却したものを電解液とした，不溶解 残渣はこれを廢㲤せる場合と $\mathrm{HF}-\mathrm{H}_{2} \mathrm{SO}_{4}$ 處理後焦性硫酸 カリ $2 \mathrm{~g}$ を加へて熔鼠し熔融物を $2 \mathrm{cc} の \mathrm{H}_{2} \mathrm{SO}_{4}(1.42)$ を含 む水 $40 \mathrm{cc}$ に溶解し濾液に合した場合とある. 電解は Cell を恒溫槽に浸した場合と然らざる場合と比較實施しだ

電解開始後所定の時間を經過した後電解を中止し電解液 の 1 滴を磁製四上にとり $1 \%$ 赤血留溶液 1 滴を加へて $\mathrm{Fe}^{++}$ の檢出を行つた後電解液を Cell よりとり出し $\mathrm{H}_{2} \mathrm{SO}_{4} 10 \mathrm{cc}$ を加へ $\mathrm{N} / 10 \mathrm{KMnO}_{4}$ 液にて湉定して $\mathrm{Fe}^{++}$の量を求め た後 $\mathrm{CO}_{2}$ を通じつ〉金屬哐鉛を用ひて $\mathrm{Fe}^{+++}$を $\mathrm{Fe}^{++}$ に還元する(4). 次に液の 1 滴をとり $\mathrm{KSCN}$ 液を用ひて䢜 元の完了したことを確めた後 $\mathrm{N} / 10 \mathrm{KMnO}_{4}$ 液で涺定して 全鐵の量を求める. この兩者の差から $\mathrm{Fe}^{+++}$量を求め た. 試料 $5 \mathrm{~g}$ の場合には電解後液を $200 \mathrm{cc}$ に稀釋, この中

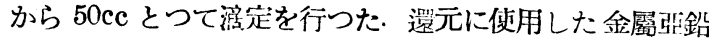
の空實驗值 は亞鉛 $1 \mathrm{~g}$ につき $\mathrm{N} / 10 \mathrm{KMnO}_{4}$ 液 $(1 \mathrm{cc}=$ $0.00553 \mathrm{gFe}$ ) $0.6 \mathrm{cc}$ であつたのでこの補正を行つた，各笔 解時間每に新しく電解液をつくり精製した水銀を用ひて電 解後分析した：電解液中の鐵の悬が僅少の場合は滨起法に よらず比色法により定董した，郎ち全鐵量を黄血䜿比色法 (5)により・又 $\mathrm{Fe}^{+++}$の量をロダンカリ比色法(6)により求 めこの兩者の差から $\mathrm{Fe}^{++}$の量を求めた

III. 實 驗 結 果

實驗結果を第 1，2，3，4表にそれぞれ示した。

第 1 表

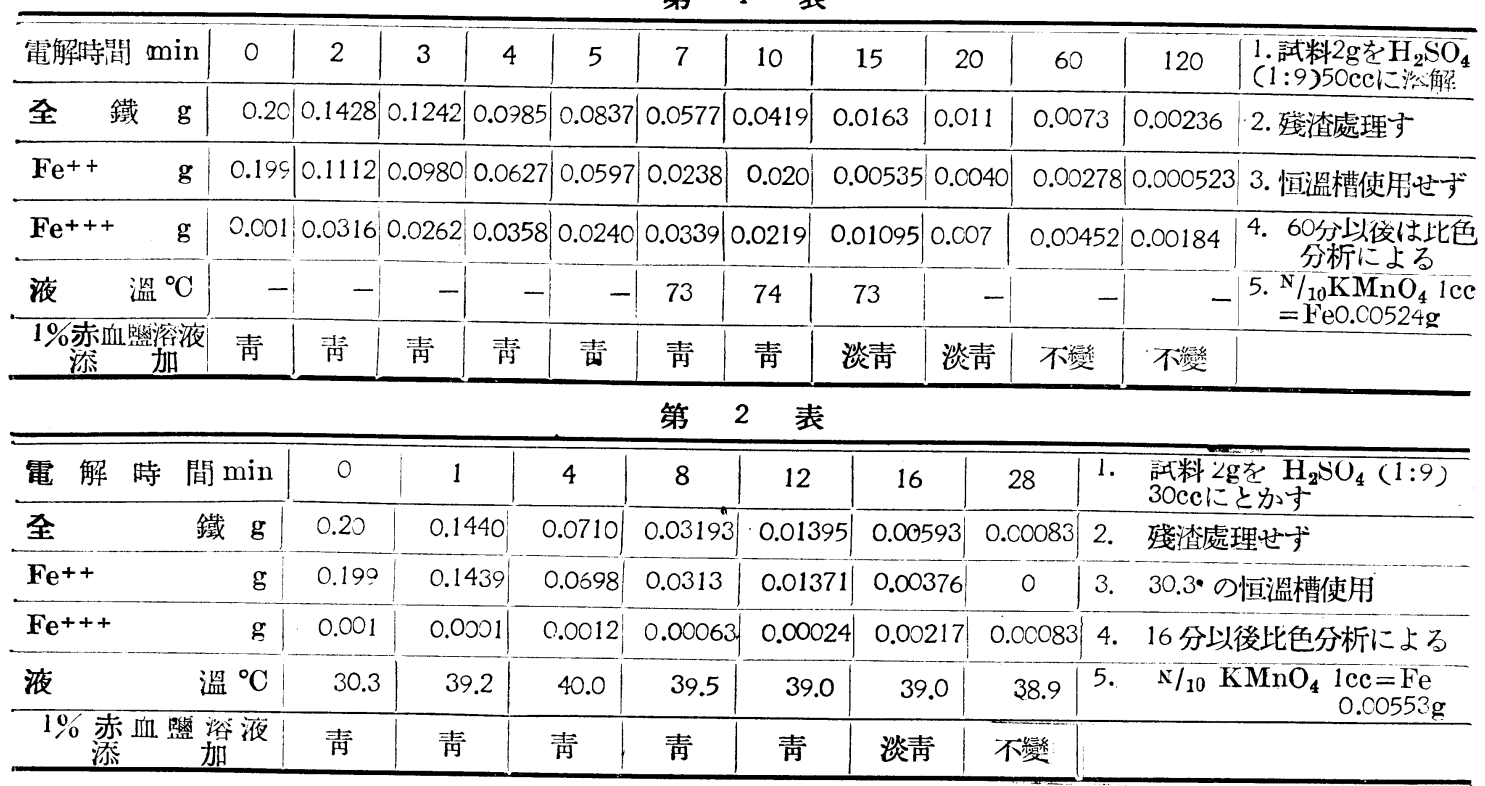


第 3 表

\begin{tabular}{|c|c|c|c|c|c|c|c|c|c|c|c|c|c|}
\hline 電解特間 min & 0 & 5 & 10 & 15 & 20 & 25 & \multicolumn{2}{|c|}{30} & 35 & 50 & \multicolumn{2}{|c|}{70} & 1. 試料 $2 \mathrm{~g} r \mathrm{H}_{2} \mathrm{SU}_{4}(1: 9)$ \\
\hline 全鐵 $\mathrm{g}$ & $0.195 \mid 0$. & 0.13340 & 0.107 & 0.0680 & 0.050 & 30.034 & \multicolumn{2}{|c|}{\begin{tabular}{l|l}
8 & 0.0232
\end{tabular}} & $0.0188 \mid 0$ & 0.0066 & \multicolumn{2}{|c|}{0.00055} & 2. 㱜些查處理せず \\
\hline $\mathrm{Fe}^{++}$ & $0.195 \mid 0$. & $0.0896 \mid 0$ & 0.0508 & 80.0337 & 0.019 & 990.012 & \multicolumn{2}{|c|}{$2|0.00498|$} & $0.0016 t$ & 0 & \multicolumn{2}{|c|}{0} & 3. 恒溫槽使朋せず \\
\hline $\mathrm{Fe}^{+++}$ & $0 \mid 0$. & 0.04380 & 0.0562 & $52 \mid 0.0345$ & 0.030 & \begin{tabular}{l|l|l}
04 & $0.022 t$
\end{tabular} & \multicolumn{2}{|c|}{0.01822} & $0.01714 \mid 0$. & $4|0.0066|$ & \multicolumn{2}{|c|}{$|0.00055|$} & 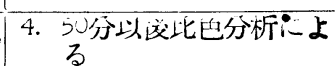 \\
\hline 液 溫 ${ }^{\circ} \mathrm{C}$ & 32.5 & 45.0 & 54.5 & 62.5 & 63.5 & 65.0 & \multicolumn{2}{|l|}{63.0} & 63.7 & 60 & \multicolumn{2}{|c|}{54} & 5. $\begin{array}{c}\mathrm{N} / 210 \mathrm{KMnO}_{4} \mathrm{Icc}=\mathrm{Fe} \\
0.00>53 \mathrm{~g}\end{array}$ \\
\hline 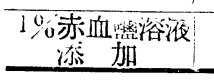 & 青 & 青 & 静 & 青 & 青 & 表 & \multicolumn{2}{|c|}{ 淡青 } & 極淡青 亚 & 呵淡击 & \multicolumn{2}{|c|}{ 不變 } & \\
\hline \multicolumn{14}{|c|}{ 第 4 表 } \\
\hline 霆解時間 min & 0 & 15 & & 30 & 45 & 60 & 90 & 120 & 180 & 270 & \multicolumn{3}{|c|}{ 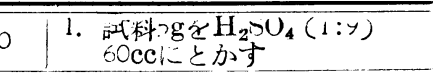 } \\
\hline 全鐵 $\mathrm{g}$ & 0.4980 & 0.387 & & $0.3088 \mid 0$ & 0.2420 & 0.1996 & 0.0996 & 0.0376 & 0.00288 & \multicolumn{4}{|c|}{\begin{tabular}{|l|l|l|}
88 & 0.00198 & 2. \\
\end{tabular}} \\
\hline $\mathrm{Fe}^{++}$ & $|0.4492|$ & 0.035 & & $0.2640 / 0$ & 0.2060 & 0.1504 & 0.0776 & 0.0345 & $15 \mid 0.03221$ & \multicolumn{2}{|c|}{\begin{tabular}{l|l|l|l|l|l|l|l|}
21 & 0.00022 & 3
\end{tabular}} & 3. 3 & $31.0^{\circ}$ の恒溫慒を使用寸 \\
\hline $\mathrm{Fe}^{+++}$ & 0.0488 & \begin{tabular}{l|l}
3 & 0.033
\end{tabular} & & 0.04480 & 0.0360 & 0.0492 & 0.0220 & 0.0031 & 0.00067 & \multicolumn{2}{|c|}{\begin{tabular}{l|l|l|l}
67 & 0.00176 & 4.
\end{tabular}} & 4. 18 & 180 分以後比色分析による \\
\hline 液 湍 ${ }^{\circ} \mathrm{C}$ & 31.0 & 38.0 & & 41.5 & 36.5 & 36.1 & 36.1 & 36.1 & 36.1 & \multicolumn{2}{|l|}{ | 36.1} & $\begin{array}{l}2+1 \\
0\end{array}$ & $\begin{array}{l}\mathrm{N} / 10 \mathrm{KMnU} / \mathrm{l} \mathrm{lcc}=\mathrm{lie} \\
0.0 \mathrm{U} 5 \mathrm{sg}\end{array}$ \\
\hline 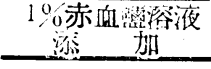 & 清 & 筩 & & 青 & 青 & 靑 & 青 & 青 & 微青 & \multicolumn{2}{|c|}{ 不鹫 } & & \\
\hline
\end{tabular}

IV. 䋨 言

上の䐝驗結果について䙩察した結果次のことが云へる.

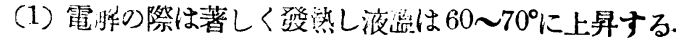

(2) 殘漼越理せざる場合について第2表の $30^{\circ}$ の恒溫槽を 使用した場合と第 3 無の㑑溫慒を使对せざる場合とを比較 すると全鐵の量が約 $10 \%$ ，に娍少するのに前者は約10分， 後者は約 35 分を要し, $1 \mathrm{mg}$ 以下となるのに前都は 28 分後 者は70分を要してるる. 從つて烈船は低溫で行ふ斿が い.

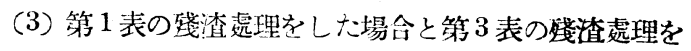
せざる場合とを比較すると全践の量が 10\% 以下になるの に前者は約 15 分, 後者は約 35 分を型し前者の方が速かに 減少するが藏の量が少くなると鐵つ分、䠊は後者の方が速く 約70分で全臷星が $1 \mathrm{mg}$ 以ドとなるに反に前者では 120 分 經逬するも $1 \mathrm{mg}$ 以下とならない。

(4) 電解の初期には殆ど大部分の嘓が $\mathrm{Fe}^{++}$として存在 し $\mathrm{Fe}^{+++}$は極く僅かしか含まれないが電解か淮むにつれ

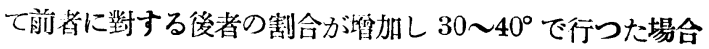

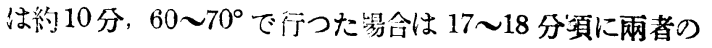
量が等しくなりそれ以後は $\mathrm{Fe}^{+++}$の方が勧倒的に多くな る.

Lundell, Hoffman 等は䉓粱の木期には溶液中に殘存 する鐵はすべて $\mathrm{Fe}^{++}$の狀態にあらうから $1 \%$ 赤血艋溶 液是用ひてFe++の檢出を行ひこれを檢出せざるに至つて 電解を終る(7)と述べてるるが著者の實驗では上述の如く Lundell, Hoffman 等の推定と全〈反對の結果を示してる る. 從つて電解末期に於ける殘留 $\mathrm{Fe}$ の憸出法子赤血盟を

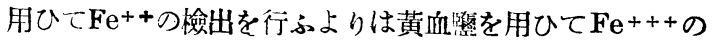
檢出を行ふ方が戴の分踓は一曆良好である.

(5) Lundell, Hoffman 等は赤血敏 指示藥を用ひて Fe+゙が憸出されない程度に至る迄の電解時間は 30 分以
內であると述べでるる(8)が著皆の賽驗で统第 2 表つ恒温慒 を使用して 30〜 $40^{\circ}$ で電解し、た場合のみ 30 分以內で赤血 溶液を加へるも青戀しない狀態に澾してるるが，第1，3表 の室內で行つた場合は何れも30分では $\mathrm{Fe}^{++}$の反應が認 められ約 60 分で赤血篮溶液により $\mathrm{Fe}^{++}$が檢出されない 紎態に達してるる。

(6) 電解液中刀 $\mathrm{Fe}$ の量は 0.2〜0.5g を越光奴洔に最良 の結果が得られると云はれてるる(す)つで $0.5 \mathrm{~g}$ を含を場合 について行つたのか第 4 表に示寸結果であるがこの場合は 恒溫槽を使用して30〜 $40^{\circ}$ で電解を行つたのにも不拘, 鐵 の量が $10 \%$ 以下に減少するのに 120 分もかっり 30 分で は約 $62 \%$ 汇減少してるるの 久であり 270 分經過するも $1 \mathrm{mg}$ 以下に娍少してるない，又 120 分頑から水銀の表面 には硬い农凯を生じてるる，郎ち溶液中に $0.5 \mathrm{~g}$ の鐵を含

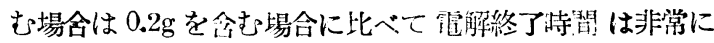
永く鐵の分跳狀况は著しく孯いことが制つた。

從つて鐵を多く含む場合には他甲方法で大部分刀鐵を分

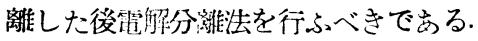

終りに御指導を戴いた後藤秀弘敋授に謝意を表する.

(1) U. S. Steel Corp., Sampling and Analysis of Carbon and Alloy Steels., (1938), 205.

(2) Lundell, Hoffman and Bright, Chemical Analysis of Iron and Steel, (1931), 47.

(3) 前出 (1), (2).

(4) Treadwell, Analytische Chemie II. Band (1930), 523.

(5) Yoe, Photochemical Analysis, Vol. 1 Colorimetry, (1928), 242.

(6) 加滕, 標準定量分析法, 300 .

$\begin{array}{llll}(7) & \text { 前出 (2) (8) 前出 (2) (9) 前出 (2) }\end{array}$

[昭和 22 年 7 月 3 日受理] 